Çukurova Üniversitesi Mühendislik Mimarlık Fakültesi Dergisi,31(2), ss. 103-117, Aralık 2016

\title{
Taş Ocaklarında Rekültivasyon Uygulaması: Uçucu Küllerin Depolanması Örneği
}

\author{
Bayram Ali MERT ${ }^{* 1}$ \\ ${ }^{1} \dot{I}$ skenderun Teknik Üniversitesi, Petrol ve Doğalgaz Mühendisliği Bölümü, İskenderun, Hatay
}

Geliş tarihi: 01.06.2016

Kabul tarihi: 23.11 .2016

Öz

Kömür yakıtlı termik santrallerden kaynaklanan atıkların birçok toksik materyal içerdiği bilinmektedir. $\mathrm{Bu}$ elementlerin su kaynaklarına sızması, atıkların bertaraf edilmesi ilgili çevresel etkileri açısından büyük önem taşımaktadır. Bu çalışmada, faaliyeti bir kaç yılda sona erecek olan bir taşocağı çukuruna termik santrallerden kaynaklı küllerin depolanması amacıyla, söz konusu taşocağının devam eden yıllarındaki üretim planlaması ve simülasyonu yapılarak kül depolama alanlarının ihtiyaçlarına cevap verebilecek şekilde tasarlanmıştır. Sonuç olarak termik santrallerden kaynaklı küllerin kalker ocağındaki depolama tesisine ilişkin projenin özellikleri, olası etkileri ve öngörülen önlemler ortaya konularak tasarım parametreleri ele alınmıştır.

Anahtar Kelimeler: Rekültivasyon, Atık depolama, Taş ocağı, Uçucu kül

\section{Reclamation of Limestone Quarry: A Case Study for the Storing of Fly Ash}

\begin{abstract}
It is known that the waste created by a coal-fired power plants include many toxic material. The elements leakage prevention to water resources by eliminating the waste is of great importance for the associated environmental effects. In this study, production planning and simulation was carried out for the suitable storage of the ash into a quarry pit which has activities will end in a few years. As a result, all of the design details were described by putting forward the precautions, possible effects and features of the project about the storage of ash created by a coal-fired.
\end{abstract}

Keywords: Reclamation, Limestone quarry, Landfill, Fly ash

\footnotetext{
*Sorumlu yazar (Corresponding author): Bayram Ali MERT, bali.mert@iste.edu.tr
} 


\section{GíRiş}

Ekonomik kalkınma ve gelişmişliğin belirleyicisi olarak önem arz eden madencilik sektörünün beraberinde getirdiği çevresel zararlar yadsınamaz bir gerçektir. Halihazırda ve terk edilmiş maden ocaklarının hem estetik açıdan, hem de çevresel açıdan çok sayıda zararları mevcuttur [1-5]. Bu çerçevede, madencilik süreçlerinde ya da sonrasında çevrenin korunmasına ve yenilenmesine yönelik önlemlerin alınması önem arz etmektedir. Bu amaçla çok sayıda yönetmelik çıkarılmış olup bunlardan biriside madencilik faaliyetleri ile bozulan arazilerin doğaya yeniden kazandırılması dair yönetmeliktir [6]. Bu yönetmeliğe göre madencilik faaliyetleri, malzeme ve toprak temini için arazide yapılan kazılar, dökümler ve doğaya bırakılan atıklarla, bozulan doğal yapının yeniden kazanılması gerekmektedir. Genel olarak rekültivasyon olarak isimlendirilen bu işlemlerin amacı madencilik faaliyeti yapılan alanın madencilik sonrası kullanımı için hazırlanmasına yönelik terk edilen alanın yeniden yararlı hale getirilmesidir [7,8]. Madencilik faaliyetlerinde çok sayıda rekültivasyon uygulaması örneği görülür. $\mathrm{Bu}$ çalışmada ise faaliyeti bir kaç yılda sona erecek olan bir taşocağ çukuruna kömür yakıtlı termik santrallerden kaynaklı küllerin depolanması amaçlanmıştır. Örnek olması açısından seçilmiş olan söz konusu termik santralde 10 yilda toplam 3,5 milyon $\mathrm{m}^{3}$ kül oluşacağı tahmin edilmektedir. Santralden kaynaklanacak uçucu kül ve cürufların bertarafi için iki alternatif öngörülmektedir. Santralden kaynaklanacak uçucu kül ve cürufların öncelikle çimento fabrikalarına verilmesi planlamaktadır. Öngörülen ikinci alternatif ise; çimento fabrikasına verilemeyen kül ve cürufların toplam 165 hektar II A Grup Kalker sahasında kurulması planlanan kül depolama tesisinde, depolanması şeklindedir. Söz konusu kalker ocağında halen faaliyet devam etmekte olup, bu çalışmada küllerin depolanması amacıyla, söz konusu kalker ocağının devam eden yıllarındaki üretim planlaması ve simülasyonu yapılmış, kazı simülasyonları sonucu elde edilen ocak çukuru Atıkların Düzenli Depolanmasına Dair Yönetmelik [9]'a uygun olarak inşa edilerek kül depolama alanı olarak kullanılması planlanmıştır. Çalışma kapsamında analitik hesaplamalar için Microsoft Excel [10], çizimler için Golden Surfer [11] ve MapInfo [12] yazılımlarından yararlanılmıştır.

\section{KALKER OCAĞININ TANIMI}

Halen faaliyet göstermekte olan kalker ocağının kazı öncesi ilk halini gösterir topografik haritası Şekil 1'de yer almaktadır.

Şekil 2'de jeoloji haritası verilmiş olan söz konusu saha kireçtaşı, dolomitik kireçtaşı ve dolomitten oluşan mezozoik yaşlı Karadağ Kireçtaşları (JKk) içinde yer almaktadır [13].

Alt dokanağında Küreci dolomiti, üst dokanağında Amanos olistrostromu ile uyumsuz olarak örtülen birimin kalınlığı yer yer 500 m'yi bulmaktadır [13, 14]. Kül depolama alanı olarak düşünülen sahada temel kayanın kireçtaşı olmasından dolayı taşıma gücü ve duyarlilık açısından bir sorun yaşanmayacağı öngörülmektedir. Hâlihazırda bulunan ocak çukuru ve yapılan kazılardan kül depolama alanının oturduğu alanda yeraltı suyu bulunmadığ bilinmektedir.

Kireçtaşı ve dolomitik kireçtaşından başka ekonomik bir maden varlığı olmayan sahada, güneyden kuzeye doğru röliyef $180 \mathrm{~m}$ kotundan 620 m kotuna kadar yükselmektedir.

Kalker ocağı sahasında açık işletme yöntemiyle ve delme-patlatma usulüyle kazı yapılmakta olup hali hazırda 1,8 milyon $\mathrm{m}^{3}$ 'lük bir ocak çukuru oluşmuş durumdadır (Şekil 3).

Termik santralin kurulum aşamasına kadar kalker üretim faaliyetlerine devam edilecek olup bu süreçte yaklaşık 1,3 milyon $\mathrm{m}^{3}$ daha kalker üretimi gerçekleştirecektir. Bu çerçevede, kalker ocağının önümüzdeki yıllar için üretim planlaması, yapılan simülasyonlar ile modellenmiş sahanın son durumunu gösterir harita ve kesitler Şekil 4-5'te sunulmuştur. 

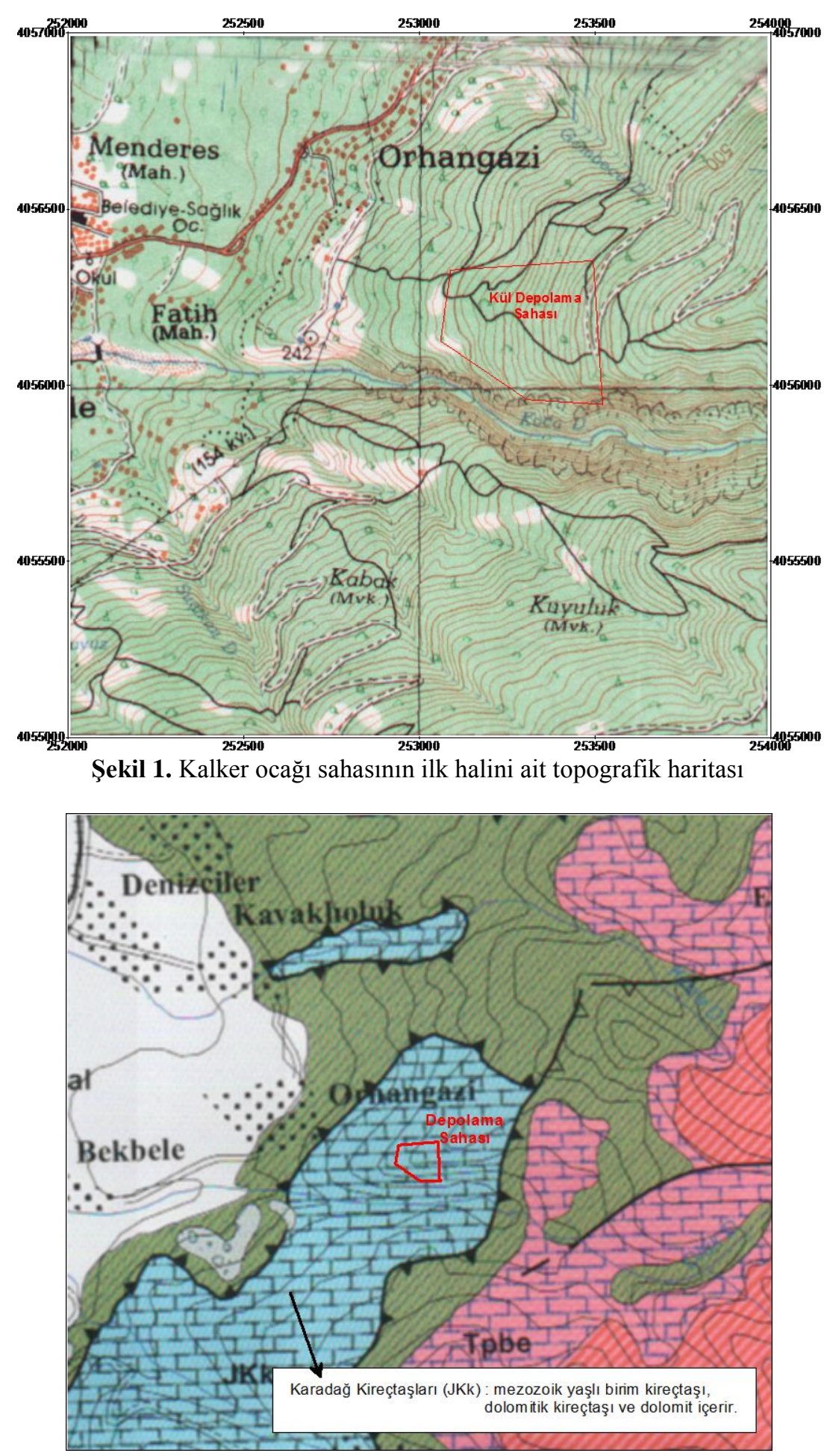

Şekil 2. Saha ve çevresini gösterir jeoloji haritası [15] 

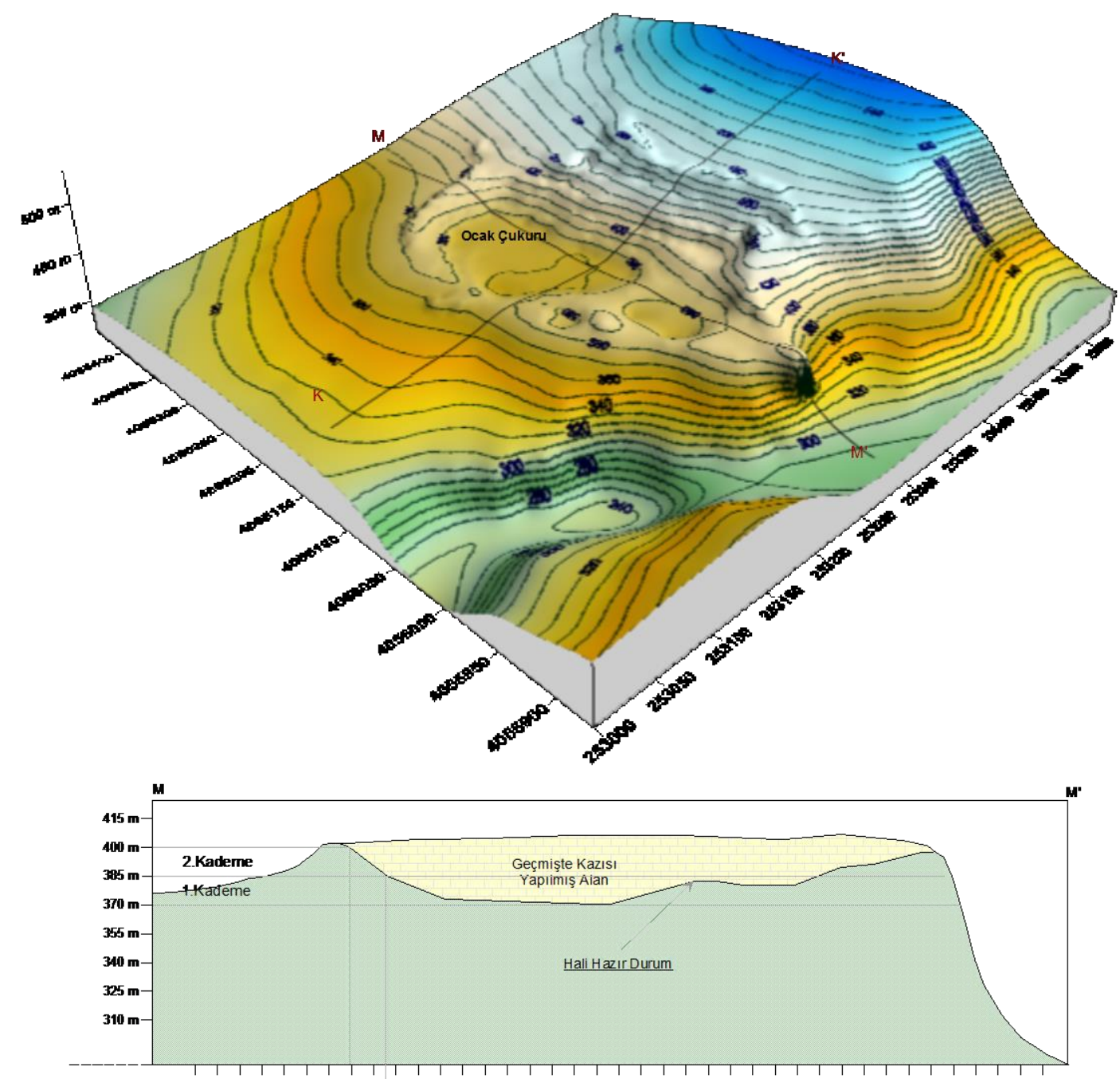

minminmmmmmmm

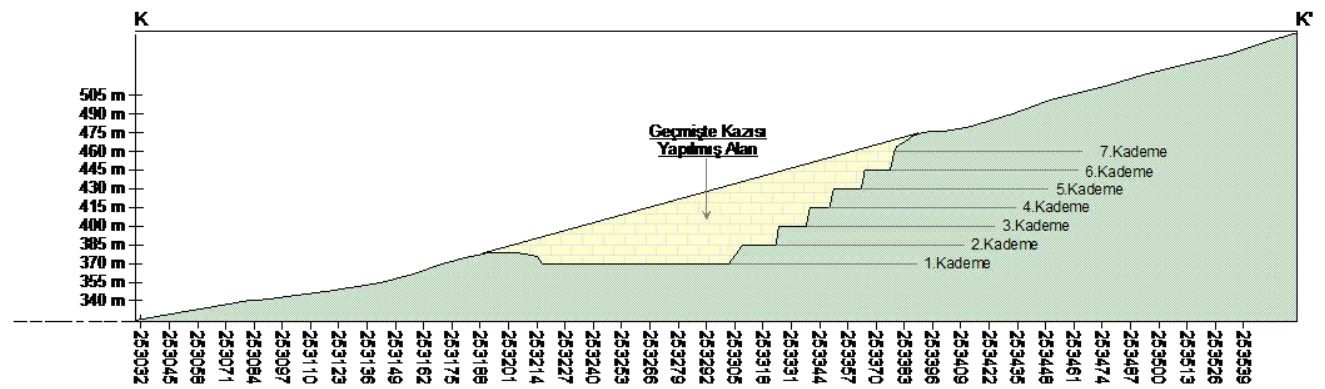

Şekil 3. Taş ocağının mevcut durumunu gösterir kesitler 
a. Yapılacak kazılar sonrası oluşacak ocak çukuru

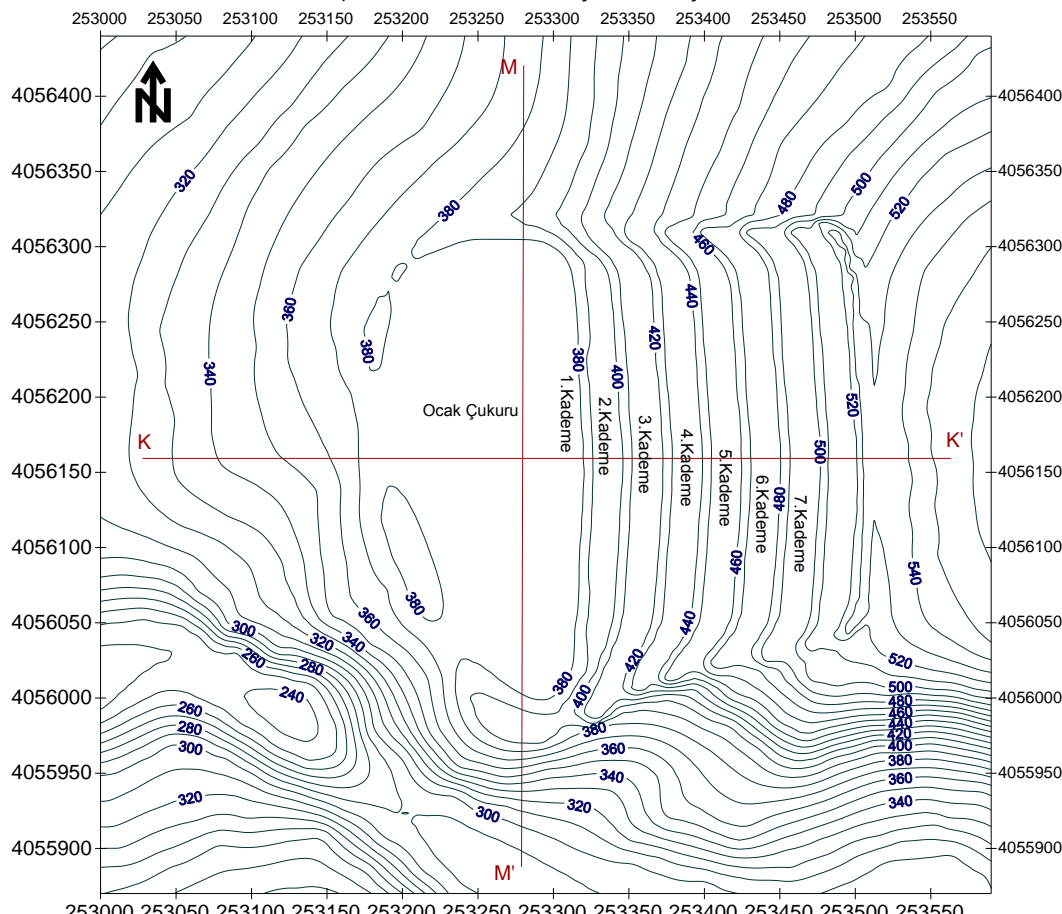

253000253050253100253150253200253250253300253350253400253450253500253550

b. Kül depolama sahası olarak düzenlenmesi sonrası oluşacak ocak çukuru

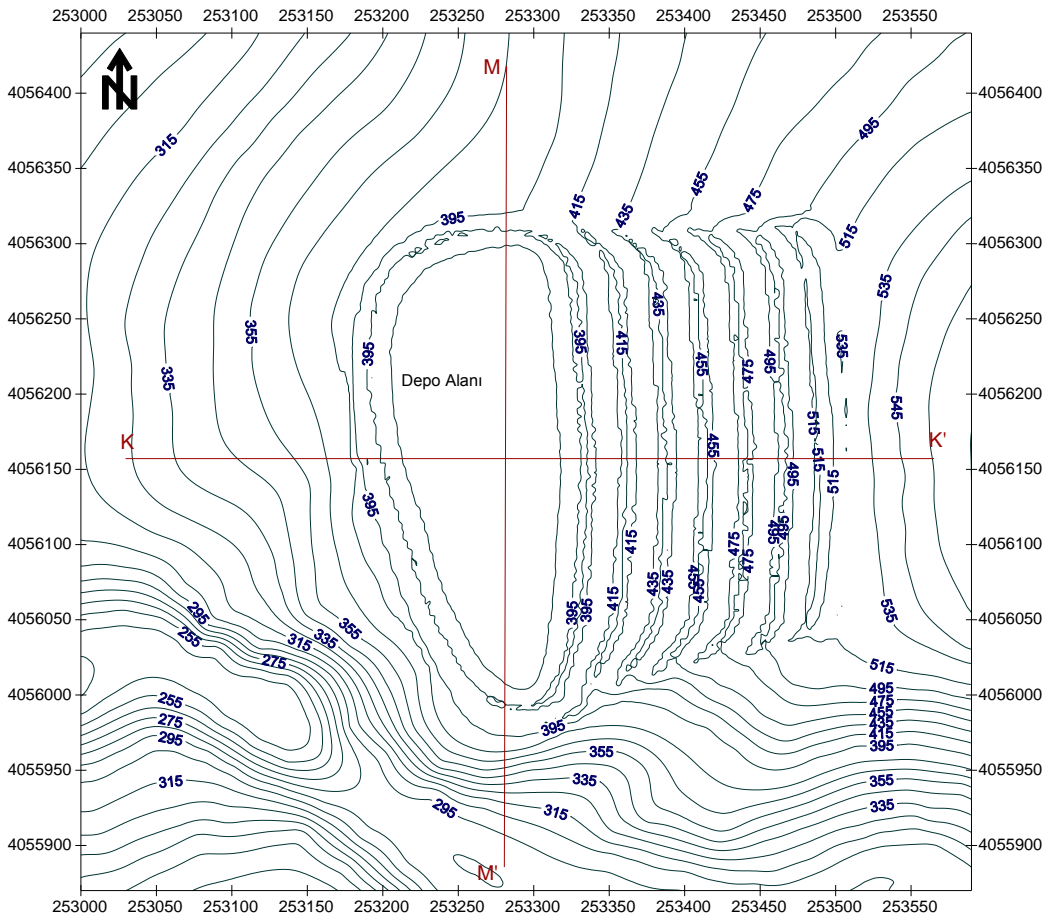

Şekil 4. Taş ocağının kazı sonrası durumunu gösterir kesitler 


\section{DEPOLAMA ALANI TASARIMI}

Kül Depolama Alanı'nda Termik Santrali'nden kaynaklanacak ve 10 y1l süre ile toplam miktarının yaklaşık $3,500,000 \mathrm{~m}^{3}$ olacağ1 öngörülen külün depolanması planlanmaktadır. $\mathrm{Bu}$ kapsamda, kalker ocağı maksimum atık depolamaya özen gösterilecek şekilde tasarlanmıştır. Tasarım çalışmaları, yukarıda belirtilmiş olan atık miktarının tamamının depolanmasına ve düzenli depolama kriterlerine uyulmasına yönelik olarak yürütülmüştür. Yapılan çalışmalar sonucunda, atık miktarının tamamının depolanabilmesi, sahanın optimum seviyede kullanılması ve en uygun tasarım geometrisinin sağlanması ile olacaktır. $\mathrm{Bu}$ çerçevede depolama alanı aşağıda verilen alt başlıklarda tanımlanmaya çalışılmıştır.

\subsection{Depolama Alanının Geometrisi}

$97,200 \mathrm{~m}^{2}$ alan ve 4,159,776,00 $\mathrm{m}^{3}$ depolama hacmine sahip Kül Depolama sahası, $7 \mathrm{~m}$ genişliğe sahip kontrol yolu ile ve $1030 \mathrm{~m}$. kuşaklama kanalı ile çevrelenecektir. En düşük 375 metre en yüksek 495 metre kotlara sahip sahada atık dolum şev eğimlerinin 3:1 (Y:D) olmas1 öngörülmektedir. Depo taban1 \%3 eğimle teşkil edilecek sahanın önüne $35 \mathrm{~m}$ yükseklikte ve $4 \mathrm{~m}$ üst, $25 \mathrm{~m}$ alt genişlikte sedde inşa edilecektir.

$\mathrm{Kazl} /$ dolgu işlerinden sonra Lot 1'deki depolama sahası taban kotu $375 \mathrm{~m}$ ile $415 \mathrm{~m}$ arasında değişecektir. Lot 2 için saha taban kotu $415 \mathrm{~m}$ ile $455 \mathrm{~m}$ arasında, Lot 3 için ise $455 \mathrm{~m}$ ile $475 \mathrm{~m}$ arasında olacaktır. Mevzuattaki hükümler gereğince atık dolum sev eğimleri 3:1 (Y:D) olarak planlanmıştır. Maksimum atık kotu 475 m olacaktır. Lot 1, Lot 2 ve Lot 3 'ün yüzey alanları sırasıyla $46,850 \mathrm{~m}^{2}, 44,910 \mathrm{~m}^{2}$ ve $36,620 \mathrm{~m}^{2}$ dir. Lot 1 için toplamda $1,610,716$ $\mathrm{m}^{3}$ 'lük brüt hacme sahip olup söz konusu hacim kayıplarının çıkarılmasından sonra elde edilecek net depolama hacmi 1,562,986 $\mathrm{m}^{3}$ olacaktır. Lot 2 toplamda 1,492,600 $\mathrm{m}^{3}$ lük brüt hacme sahip olup net depolama hacmi $1,470,190 \mathrm{~m}^{3}$ 'tür. Lot 3 ise toplamda $1,142,650 \mathrm{~m}^{3}$, lük brüt hacme sahip olup net depolama hacmi $1,126,600$ $\mathrm{m}^{3}$ 'tür. 3 boyutlu arazi modellemeleri sonucunda, Atık Depolama Alanı için toplamda yaklaşık 4,159,776 $\mathrm{m}^{3}$ depolama hacmi ortaya çıkmaktadır. Bu hacim miktarına taban geçirimsizlik sistemi ile oluşacak hacim kayıpları da dâhildir.

Sonuç olarak, toplam net atık depolama kapasitesi $4,159,776 \mathrm{~m}^{3}$ olacaktır ve 11,5 yıllık bir hizmet süresi sağlayacaktır. Uçucu küllerin çimento sanayine verilmesi söz konusu olmasına rağmen uçucu küllerin satılamadığ durum da dahi, 10 yıllık atık miktarının depolanması garanti edilmiş durumdadır. Proje kapsamında tesis edilmesi planlanan kül depolama alanına ait 3 boyutlu görünümler Şekil 5 'te verilmektedir.

Lotların dolum kesiti Şekil 6'da görülmektedir. Lotların kazı ve kül dolgu kapasiteleri bilgisayar yazılımı ile hesaplamış ve özet olarak Çizelge 1 'de verilmiştir.

Çizelge 1. Lotların kül dolgu kapasitesi

\begin{tabular}{|c|c|c|c|c|c|c|c|c|c|}
\hline Lot & $\begin{array}{c}\text { Kad. } \\
\text { No }\end{array}$ & $\begin{array}{c}\text { Kademe } \\
\text { Uzunluk } \\
\text { (m) }\end{array}$ & $\begin{array}{l}\text { Kazı } \\
\text { Alanlar } \\
\left(\mathrm{m}^{2}\right)\end{array}$ & $\begin{array}{c}\text { Kazı } \\
\text { Hacimleri } \\
\left(\mathrm{m}^{3}\right)\end{array}$ & $\begin{array}{l}\text { Kül Dolgu } \\
\text { Alanlar } \\
\left(\mathrm{m}^{2}\right)\end{array}$ & $\begin{array}{l}\text { Kül Dolgu } \\
\text { Yükseklik } \\
\left(\mathrm{m}^{2}\right)\end{array}$ & $\begin{array}{c}\text { Kül Dolgu } \\
\text { Kapasitesi } \\
\left(\mathrm{m}^{3}\right)\end{array}$ & $\begin{array}{c}\text { Lot } \\
\text { Kapasite } \\
\left(\mathrm{m}^{3}\right)\end{array}$ & $\begin{array}{c}\text { Ömür } \\
(\mathrm{y} 1 \mathrm{l})\end{array}$ \\
\hline \multirow{2}{*}{1} & 1. & 315 & 208,42 & $65,652,60$ & 32860 & 20 & 657,200 & \multirow{2}{*}{$1,562,986$} & 1,83 \\
\hline & 2. & 349 & 358,93 & $125,267,56$ & 46690 & 19,4 & 905,786 & & 2,52 \\
\hline \multirow{2}{*}{2} & 3. & 304 & 602,88 & $183,275,95$ & 37280 & 20 & 745,600 & \multirow{2}{*}{$1,470,190$} & 2,07 \\
\hline & 4. & 306 & 911,92 & $279,047,98$ & 37350 & 19,4 & 724,590 & & 2,01 \\
\hline \multirow{3}{*}{3} & 5. & 293 & 484,37 & $141,920,63$ & 29580 & 20 & 591,600 & \multirow{2}{*}{$1,126,600$} & 1,64 \\
\hline & 6. & 292 & 516,82 & $150,911,05$ & 26750 & 20 & 535,000 & & 1,49 \\
\hline & 7. & 286 & 210,67 & $60,250,33$ & & & & & \\
\hline \multicolumn{4}{|c|}{ TOPLAM } & $1,006,326,11$ & & & \multicolumn{2}{|c|}{$4,159,776,00$} & 11,55 \\
\hline
\end{tabular}



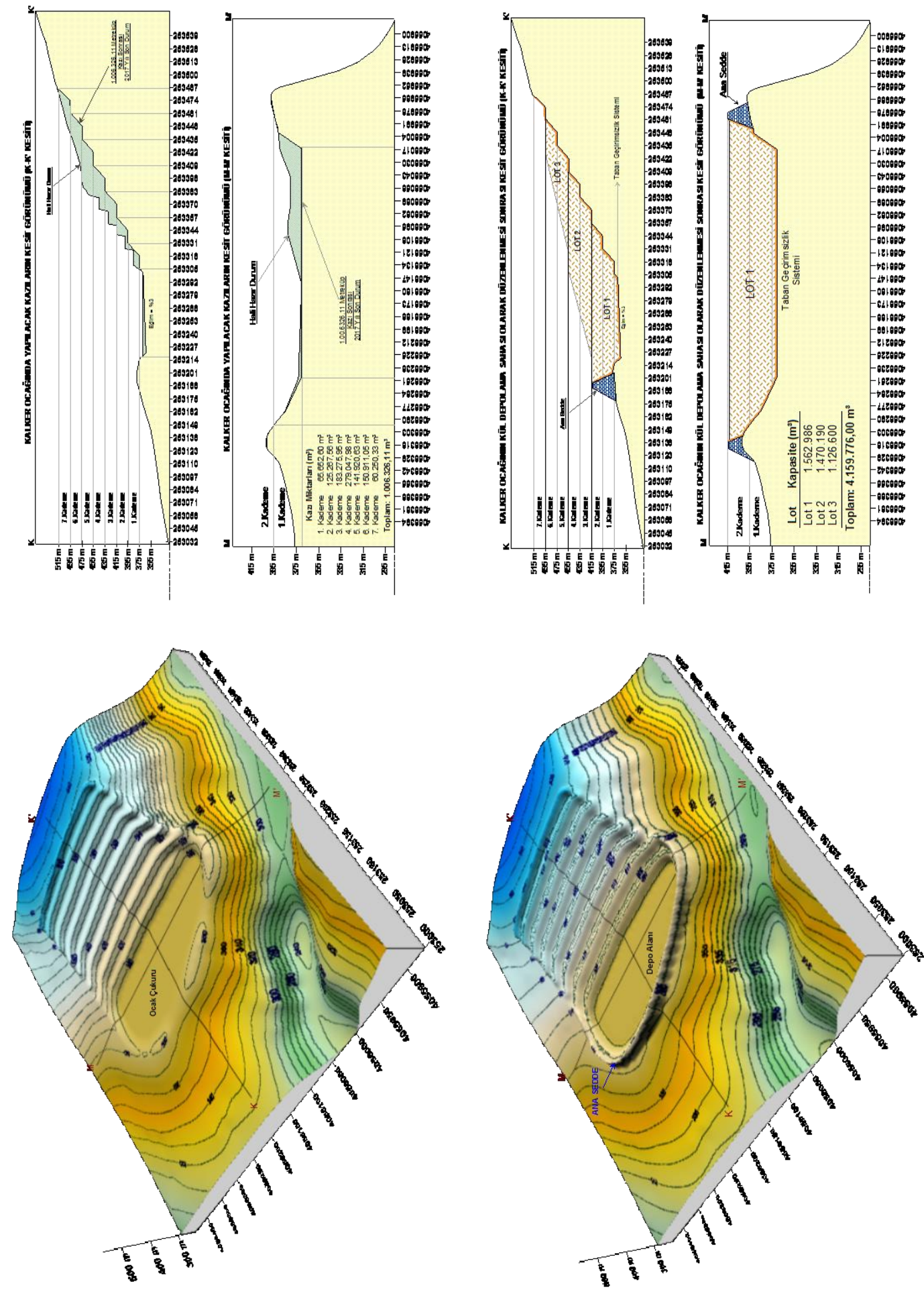

Şekil 5. Taş ocağında tasarlanan düzenli depolama lotlarının dolgu kesitleri 


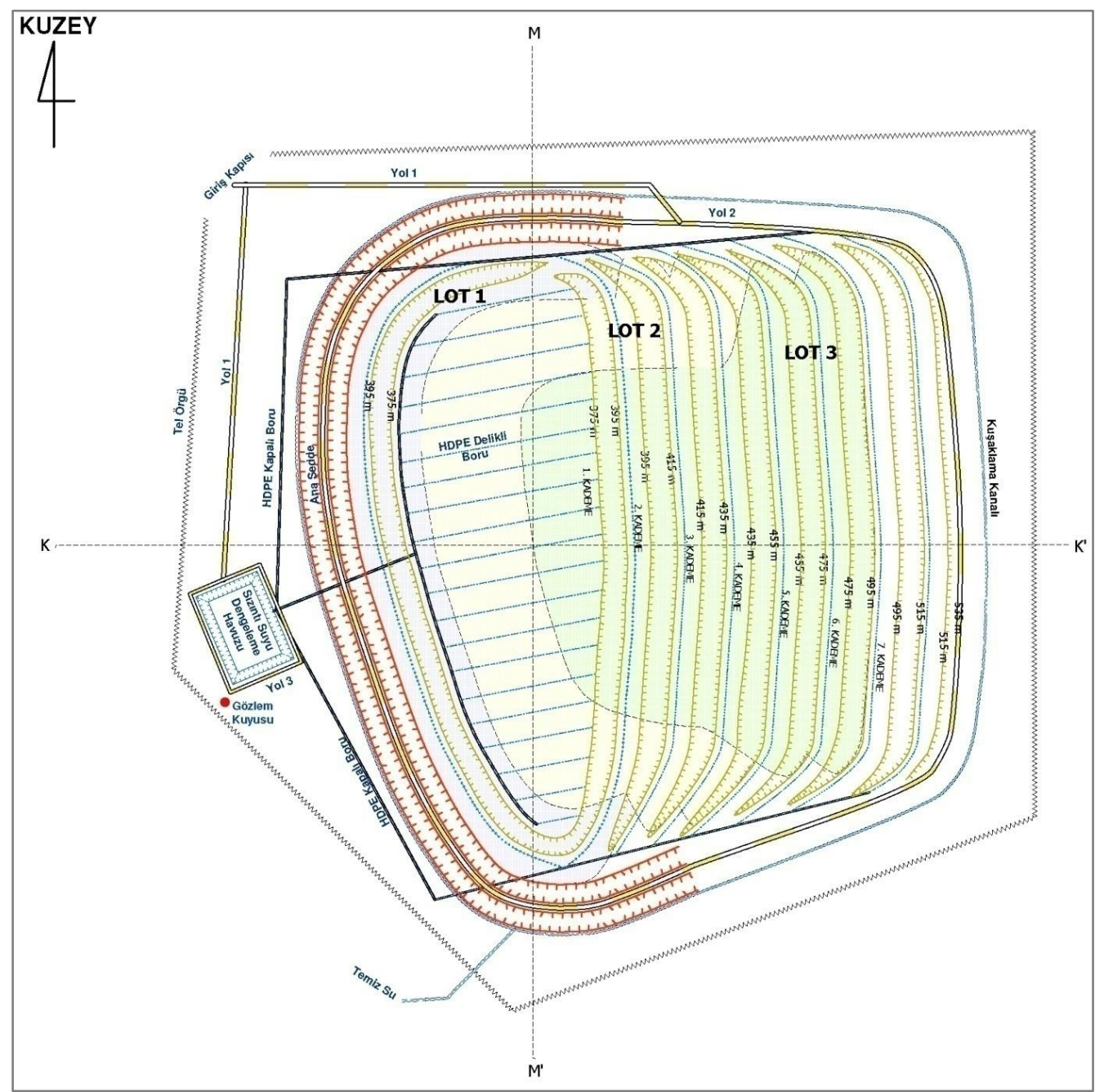

Şekil 6. Düzenli depolama tesisinin genel hatları

\subsection{Depolama Alanı Taban Geçirimsizlik Sistemi}

Depolama alanının tabanında, zemine ve yeraltı suyuna sızıntı suyu girişini önlemek amacıyla taban geçirimsizlik sistemi uygulanacaktır. Uygulanacak olan taban geçirimsizlik sisteminin alttan üste doğru,

- Geçirimsizlik Tabakası,

- Plastik Örtü,

- Jeotekstil Örtü,

- Drenaj Tabakası, olarak teşkil edilmesi öngörülmektedir. $\mathrm{Bu}$ çerçevede Lot tabanı $60 \mathrm{~cm}$ kalınlığında sıkıştırılmış kil ile kaplanacak ve üzerine $2 \mathrm{~mm}$ HDPE membran serilecektir. Kullanılan kilin geçirimlilik katsayısı (permeabilite) $\mathrm{K} \leq 1,0 \times 10^{-9}$ $\mathrm{m} / \mathrm{sn}$ olacaktır. Membranın üzerine koruma amaçlı jeotekstil kullanılacaktır. Oluşan sızıntı sularını toplamak için, jeotekstil üzerine drenaj boruları ve $50 \mathrm{~cm}$ çakıl dren tabakası $\left(\mathrm{K} \geq 1,0 \times 10^{-4} \mathrm{~m} / \mathrm{s}\right.$ geçirgenliğe sahip) teşkil edilecektir. U çerçevede taban geçirimsizlik sisteminin uygulanacağı alanlar ve kullanılacak kil ve çakılın ortalama hacimleri hesaplanmış ve Çizelge 2'de sunulmuştur. 
Çizelge 2. Taban geçirimsizlik sisteminin uygulanacağı yüzeyler

\begin{tabular}{|c|c|c|c|c|}
\hline Lot & Kademe No & Uygulama Alanı $\left(\mathrm{m}^{2}\right)$ & Kil Miktarı $\left(\mathrm{m}^{3}\right)$ & Çakıl Miktarı $\left(\mathrm{m}^{3}\right)$ \\
\hline \multirow{2}{*}{1} & 1. & $32.860,00$ & $19.716,00$ & $16.430,00$ \\
\cline { 2 - 5 } & 2. & $4.880,00$ & $2.928,00$ & $2.440,00$ \\
\hline \multirow{2}{*}{2} & 3. & $4.519,00$ & $2.711,40$ & $2.259,50$ \\
\cline { 2 - 5 } & 4. & $3.848,00$ & $2.308,80$ & $1.924,00$ \\
\hline \multirow{2}{*}{3} & 5. & $3.044,00$ & $1.826,40$ & $1.522,00$ \\
\cline { 2 - 5 } & 6. & $5.101,00$ & $3.060,60$ & $2.550,50$ \\
\hline \multicolumn{2}{|c|}{ TOPLAM } & $4.028,00$ & $2.416,80$ & $2.014,00$ \\
\hline
\end{tabular}

II. sınıf düzenli depolama tesisi için uyulması gereken ulusal mevzuatının depo tabanı kaplaması ile ilgili öngörmüş olduğu standartlar " $K \leq 1,0 x$ $10^{-9} \mathrm{~m} / \mathrm{sn} ;$ kalınlık $\geq 1 \mathrm{~m}$ veya eşdeğeri Kil (Mineral) tabaka" şeklindedir. Bu şartlar doğal olarak sağlanamaması halinde; bu tabaka yapay olarak oluşturulur ve jeo membran kullanılarak güçlendirilir. Geçirimsiz mineral malzeme ile yapay olarak oluşturulacak geçirimsizlik tabakasının toplam kalınlığı 0,6 metreden az olamaz. Bu kapsamda, depolama alanının üç tarafını çevreleyen yaklaşık $20 \mathrm{~m}$ yüksekliğindeki kaya palyaların yüzeyleri önce traşlanarak düz bir hale getirilecektir. Daha sonra hasir donatıl1 püskürtme beton ile kaplanacaktır. Püskürtme beton üzerinde geotekstil ve membranı delecek çıkıntılar olmamasına dikkat edilecektir. Püskürtme beton ile boşlukları ve pürüzlüğü giderilemeyen, düz bir yüzey elde edilemeyen durumlarda perde beton kullanılacaktır. Böylece HDPE membranın yırtılmasına sebep olacak palyaların yüzeyinde bulunan boşluk ve pürüzlülükler giderilerek düz bir yüzey elde edilecektir. Bu çerçevede, uygulama yapılacak yüzey alanları Çizelge 3'de verilmiştir.

Çizelge 3. Palya yan yüzeyleri geçirimsizlik sisteminin uygulanacağ 1 alanlar

\begin{tabular}{|c|c|c|}
\hline Lot & Kademe No & Uygulama Alan1 $\left(\mathrm{m}^{2}\right)$ \\
\hline \multirow{2}{*}{ LOT 1 } & 1. Kademe & $9.004,00$ \\
\cline { 2 - 3 } & 2. Kademe & $5.065,00$ \\
\hline \multirow{2}{*}{ LOT 2 } & 3. Kademe & $4.831,00$ \\
\cline { 2 - 3 } & 4. Kademe & $5.863,00$ \\
\hline \multirow{2}{*}{ LOT 3 } & 5. Kademe & $4.689,00$ \\
\cline { 2 - 3 } & 6. Kademe & $4.777,00$ \\
\hline & 7. Kademe & $4.691,00$ \\
\hline & & $38.920,00 \mathrm{~m}^{2}$ \\
\hline
\end{tabular}

Atıkların Düzenli Depolanmasına Dair Yönetmelik [9] gereği, daha sonra palyalara önce koruma amaçlı geotekstil sonra HDPE membran ve üzerine de tekrar koruma amaçlı geotekstil serilecektir. HDPE membran altında ve üzerinde bulunan geotekstil ile birlikte zemin içine ankrajlanacaktır. Ankraj çukuru $1 \mathrm{~m}$ derinlikte olacaktır. Ankraj çukuru tabanına $10 \mathrm{~cm}$ kum serilecek ve jeotekstil
+ HDPE membran + geotekstil üzeri tamamen kum ile doldurulacaktır. 97,200 $\mathrm{m}^{2}$ alana sahip kül depolama sahası, atık bertarafı tamamlandığında, depolama sahasının üzeri kapatılacaktır. İlgili yönetmeliğe göre gerçekleştirilmesi gereken üst örtü geçirimsizlik sisteminin alttan üste doğru; 
- Tesviye Tabakasi,

- Mineral Geçirimsizlik Tabakası,

- Drenaj Tabakasi,

- Toprak Tabakası, şeklindedir.

\subsection{Sızıntı Suyu Drenajı}

Kül depolama tesisi içerisine su girişi; ağırlıklı olarak yağış dolayısıyla oluşmaktadır. Sızıntı suyu yağışa bağımlı olduğundan, bölgedeki meteorolojik faktörler sızıntı suyu oluşumunda etkili olmaktadır. Sızıntı suyu oluşumunda yağış gibi önemli bir yer tutan diğer meteorolojik olay buharlaşmadır. Serbest su yüzeyinden buharlaşmanın aksine, toprak yüzeyinden buharlaşma yeraltı suyu seviyesi, zemin ve bitki örtüsü cinsi, vb. gibi birçok etkene bağlıdır. Dolayısıyla, depolama sahası su çevriminin sürdüğü bir atık kütlesi olarak incelenmelidir.

Kül Depolama Sahası sızıntı suyunun oluşumuna etki edecek olan yağış ve buharlaşma değerleri Hatay İli, İskenderun İlçesi Meteoroloji
İstasyonuna ait olup Meteoroloji İl Müdürlüğü’nden alınmıştır. Bu bilgiler 1şı̆̆ında, kül depolama sahası için, sızıntı suyu oluşum miktarları belirlenmiş olup Çizelge 4'de verilmiştir.

Çizelge 4'te kül depolama sahasında meydana gelecek olan sızıntı suyu miktarları, havuza net giriş miktarları, havuzdaki net su miktarı ve geri devir miktarları verilmektedir. Çizelge incelendiğinde, sızıntı suyu miktarları aylık bazda gösterilmiştir. Çizelge 4'e göre havuza net giriş debisi maksimum $6,643,43 \mathrm{~m}^{3} /$ ay $(2,56 \mathrm{lt} / \mathrm{sn})$, havuza net girişin ortalama debisi ise 3,243,240 $\mathrm{m}^{3} /$ ay $(1,20 \mathrm{lt} / \mathrm{sn})$ olmaktadır. Maksimum geri devir debisi $1603,58 \mathrm{~m}^{3} /$ ay $(0,16 \mathrm{lt} / \mathrm{sn})$, ortalama geri devir debisi ise $422,804 \mathrm{~m}^{3} /$ ay $(0,163 \mathrm{lt} / \mathrm{sn})$ olmaktadır.

Yapılan hesaplamalarda, Kül Depolama Alanı= 90,720,00 $\mathrm{m}^{2}$; Sizınt Su Havuz Alanı = 1,750,00 m² Havuz Brüt Hacim= 6,460,00 $\mathrm{m}^{3}$; Havuz Net Su Hacmi $=5,168,00 \mathrm{~m}^{3}$ olarak alınmıştır.

Çizelge 4. Sızıntı suyu oluşum miktarları

\begin{tabular}{|c|c|c|c|c|c|c|c|c|c|c|}
\hline$\frac{\bar{\pi}}{\grave{2}}$ & 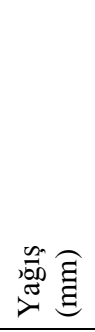 & 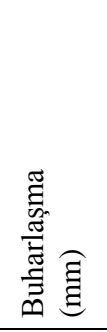 & 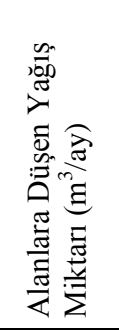 & 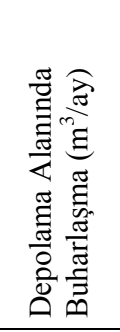 & 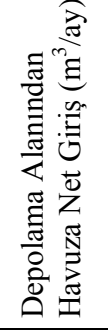 & 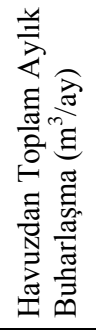 & 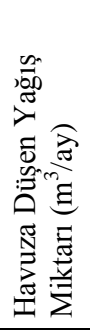 & 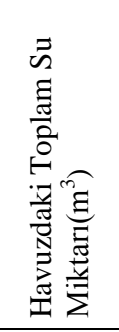 & 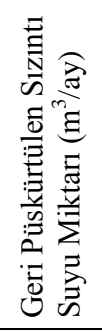 & 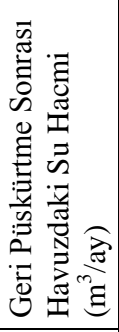 \\
\hline Ocak & 84,00 & 58,70 & 7620,4 & 1597,5 & 6022,9 & 30,82 & 147,0 & 6139,0 & 971,0 & 5168 \\
\hline Şubat & 88,90 & 59,70 & 8065,0 & 1624,8 & 6440,2 & 31,34 & 155,5 & 6564,4 & 1396,4 & 5168 \\
\hline Mart & 85,70 & 86,40 & 7774,7 & 2351,4 & 5423,2 & 45,36 & 149,9 & 5527,8 & 359,8 & 5168 \\
\hline Nisan & 64,50 & 111,90 & 5851,4 & 3045,4 & 2805,9 & 58,75 & 112,8 & 2860,1 & 0,00 & 5180 \\
\hline Mayıs & 45,00 & 146,60 & 4082,4 & 3989,8 & 92,5 & 76,97 & 78,75 & 94,3 & 0,00 & 5160 \\
\hline Haziran & 34,30 & 177,10 & 3111,7 & 4819,9 & 0,00 & 92,98 & 60,03 & 0,00 & 0,00 & 5168 \\
\hline Temmuz & 9,70 & 192,70 & 879,9 & 5244,5 & 0,00 & 101,17 & 16,98 & 0,00 & 0,00 & 5168 \\
\hline Ağustos & 18,20 & 187,50 & 1651,1 & 5103,00 & 0,00 & 98,44 & 31,85 & 0,00 & 0,00 & 5168 \\
\hline Eylül & 38,00 & 158,80 & 3447,36 & 4321,90 & 0,00 & 83,37 & 66,50 & 0,00 & 0,00 & 5168 \\
\hline Ekim & 80,40 & 112,10 & 7293,89 & 3050,91 & 4242,9 & 58,85 & 140,7 & 4324,82 & 0,00 & 5168 \\
\hline Kasım & 86,60 & 75,60 & 7856,35 & 2057,53 & 5798,8 & 39,69 & 151,5 & 5910,68 & 742,68 & 5168 \\
\hline Aralık & 92,10 & 62,90 & 8355,31 & 1711,89 & 6643,4 & 33,02 & 161,1 & 6771,58 & 1603,5 & 5168,0 \\
\hline Aylik Ort. & 60,61 & 119,16 & 5499,14 & 3243,24 & 3122,5 & 62,56 & 106,0 & 3182,74 & 422,80 & 5168,0 \\
\hline Günlük Ort. & 1,99 & 3,92 & 180,79 & 106,63 & 102,66 & 2,06 & 3,49 & 104,64 & 13,90 & 169,91 \\
\hline
\end{tabular}


Kül Depolama Sahası taban izolasyonunda yer alacak sizıntı suları sahanın tabanında yerleştirilmiş HDPE perfore borular ile toplanacak ve kendi cazibelerinden yararlanarak sızıntı suyu depolama havuzuna taşınacaktır. Havuz kapasitesinin belirli bir seviyeye ulaşması durumunda, sızıntı suyu, geri devir bacasında yer alan pompalar sayesinde depolama sahasina geri pompalanarak (resirkülasyon) yüzeysel sızdırma ile geri devrettirilecektir. Depolama alanında sızıntı suyu geri devrettirildiği zaman, sızıntı suyu, kütlede kısır bir döngü içerisinde hareket edecek ve her çevrimde açık hava ile temasa geçerek buharlaşma ile zaman içinde hacminde önemli azalmalar meydana gelecektir. Geri devir işlemi ile daha da önemlisi, külün nemlendirilmesine yardımcı olunacak ve tozuma gibi çevreyi olumsuz yönde etkileyecek problemlerin önüne geçilmiş olunacaktır. Sonuç olarak, gerek yatırım gerekse işletme maliyetleri göz önünde bulundurularak, kül depolama alanında sızıntı sularının geri devir ettirmek suretiyle bertarafı gerçekleştirilecektir.

Sizıntı suyu depolama havuzu $5,168 \mathrm{~m}^{3}$ olarak boyutlandırılmıştır (Şekil 7). Havuzun sayısal özellikleri aşağıda verilmiştir.

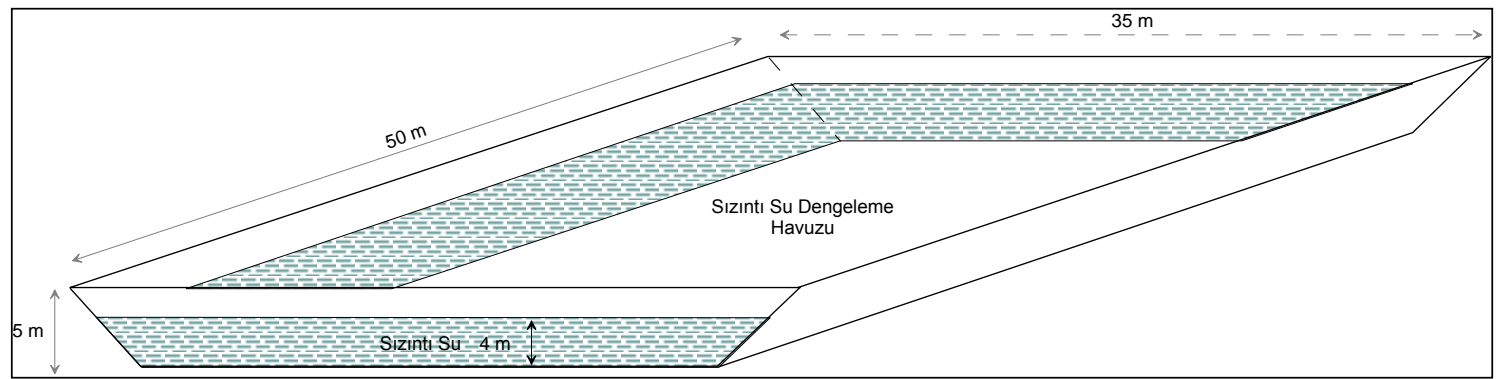

Şekil 7. Sizıntı suyu depolama havuzu ölçüleri

Havuz Üst Alanı $=35$ x $50=1,750 \mathrm{~m}^{2}$

Hava Payı Sonrası Üst Alan $=33 \mathrm{x} 48=1,584 \mathrm{~m}^{2}$ Havuz Taban Alanı $=25 \times 40=1000 \mathrm{~m}^{2}$

$\mathrm{Su}$ Yüksekliği $=4 \mathrm{~m}$

Kullanılabilir Havuz Hacmi $=(1,750+1,000) \mathrm{x}$ $4 / 2=5,168 \mathrm{~m}^{3}$

Havuza net giriş ortalaması 102,66 m³/gün olarak hesaplanmıştır. Dolayısıyla, havuzun ortalamada 50 günlük su depolama kapasitesi mevcuttur. Havuza 20 yıllık yağış ortalamalarında maksimum net giriş $221,45 \mathrm{~m}^{3} /$ gün olarak hesaplanmıştır. Dolayısıyla, havuzun maksimum yağış şartlarında 23 günlük su depolama kapasitesi mevcuttur.

\subsection{Yüzeysel Sularının Uzaklaştırılması}

Kül depolama sahasında, atığın olduğu bölümün dışındaki alandan yağış dolayısıyla oluşan yüzey sularının, atık döküm sahasına girmesini engellemek için yüzey suyu drenaj kanalları (kuşaklama kanalı) planlanmıştır. $\mathrm{Bu}$ amaçla, yüzey suyu drenaj kanalları, saha çevresinde belirli k1sımlarda, arazinin topografyasına ve sahanın geometrisine göre yerleştirilecektir. Kanallar yol eğimleri ile yüzey suyunun toplanacağı biçimde teşkil edilecektir.

Havzaya ait meteorolojik parametrelerden en şiddetli akışın meydana geleceği öngörüsü ile gerçekleştirilen yüzey suyu drenaj kanalı hidrolik boyutlandırma hesapları aşağıda verilmiştir. Kül depolama alanına topografik eğimler dikkate alındığında 12 ha'lık bir kısımdan yağış suları kuşaklama kanalına gelecektir (Şekil 8).

Hesaplarda 10 dk'lık ve 20 yıllık yağış göz önüne alınırsa İskenderun İlçesi için maksimum yağış şiddeti $171 \mathrm{~mm} / \mathrm{saat}$ olarak bulunur. Ormanlık alanda akış katsayısı 0,3 alınarak kanala gelecek debi; $(171 \mathrm{~mm} / \mathrm{sa}) *\left(152,482,72 \mathrm{~m}^{2}\right) * 0,3 /(3600$ $\mathrm{sa} / \mathrm{sn})=2,816 \mathrm{lt} / \mathrm{sn}$ hesaplanır.

Kuşaklama kanalı arazinin topografyasına ve sahanın geometrisine göre farklı eğimlerde, 
betonarme trapez kesit olacaktır. Kanal hesabı detayları Manning [16]'da verilen ManningStrickler formülü kullanılmıştır.

$\mathrm{V}=1 / \mathrm{n} \mathrm{x} \mathrm{V}^{2 / 3} \times \mathrm{J}^{1 / 2}$

$\mathrm{V}$ : akış hızı, m/sn

R: hidrolik yarıçap, $(\mathrm{F} / \mathrm{U}), \mathrm{m}$

F: 1slak kesit, $\mathrm{m}^{2}$

$\mathrm{U}$ : 1slak çevre, $\mathrm{m}$

$\mathrm{n}$ : Manning formülünde pürüzlülük katsayısı, boyutsuz

$\mathrm{n}=0.012$ (beton kanal için)
Manning-Strickler formülü kullanarak boyutlandirılan trapez kanalın hesabı Çizelge 5'de verilmiştir. Şekil 9'da kesiti görüldüğü gibi kanalın taban genişliği $1 \mathrm{~m}$, yüksekliği $0,6 \mathrm{~m}$ yan yüzeylerin eğimi $1 / 1$ ve üst genişliği 2,0 m olacaktır. Bu kanalın eğimi 1/30 olacaktır. Kanalda su yüksekliği 0,38 m olmaktadır. Kanal tam dolu halde $2,967 \mathrm{~m}^{3} / \mathrm{sn}$ debi taşıyabildiğinden emniyetli tarafta kalınmıştır. Şekil 6'da görülen ve depolama alanını çepeçevre saran kuşaklama kanalı toplam uzunluğu L= 1268 m'dir.
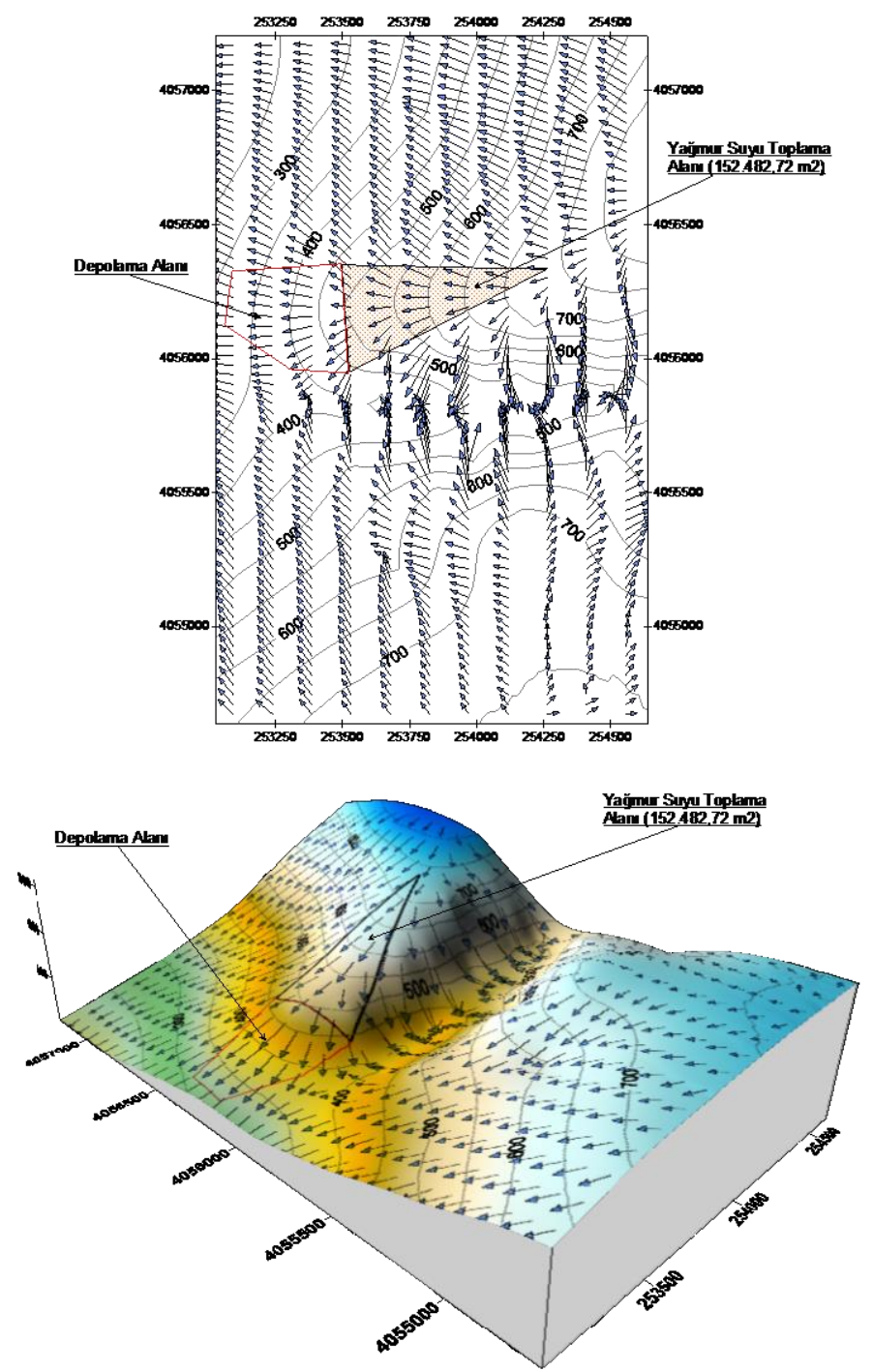

Şekil 8. Kuşaklama kanalı su toplama havzası 
Çizelge 5. Çevre (kuşaklama) kanalı hesabı

\begin{tabular}{|c|c|c|c|c|c|c|c|c|c|c|}
\hline $\begin{array}{c}\text { Akış } \\
\text { Katsayıs }\end{array}$ & $\begin{array}{c}\text { Hesap } \\
\text { Debisi }\end{array}$ & Eğim & \multicolumn{2}{|c|}{$\begin{array}{c}\text { Trapez } \\
\text { Kanal }\end{array}$} & $\begin{array}{c}\text { Su } \\
\text { Yüksekliği }\end{array}$ & $\begin{array}{c}\text { Islak } \\
\text { Alan }\end{array}$ & $\begin{array}{c}\text { Islak } \\
\text { Çevre }\end{array}$ & $\begin{array}{c}\text { Hidroklik } \\
\text { Yarıçap }\end{array}$ & Hiz & $\begin{array}{c}\text { Kanalın } \\
\text { Max. } \\
\text { Debisi }\end{array}$ \\
\hline $\mathrm{C}$ & $\mathrm{Q}$ & $1: \mathrm{A}$ & $\mathrm{B}$ & $\mathrm{H}$ & $\mathrm{h}$ & $\mathrm{F}$ & $\mathrm{U}$ & $\mathrm{R}$ & $\mathrm{V}$ & $\mathrm{Qmax}$ \\
\hline & $\mathrm{m}^{3} / \mathrm{sn}$ & & $\mathrm{m}$ & $\mathrm{m}$ & $\mathrm{m}$ & $\mathrm{m}^{2}$ & $\mathrm{~m}$ & $\mathrm{~m}$ & $\mathrm{~m} / \mathrm{sn}$ & $\mathrm{m}^{3} / \mathrm{sn}$ \\
\hline 0,300 & 1,265 & 30 & 0,80 & 0,60 & 0,38 & 0,45 & 1,87 & 0,24 & 2,81 & 2,967 \\
\hline
\end{tabular}

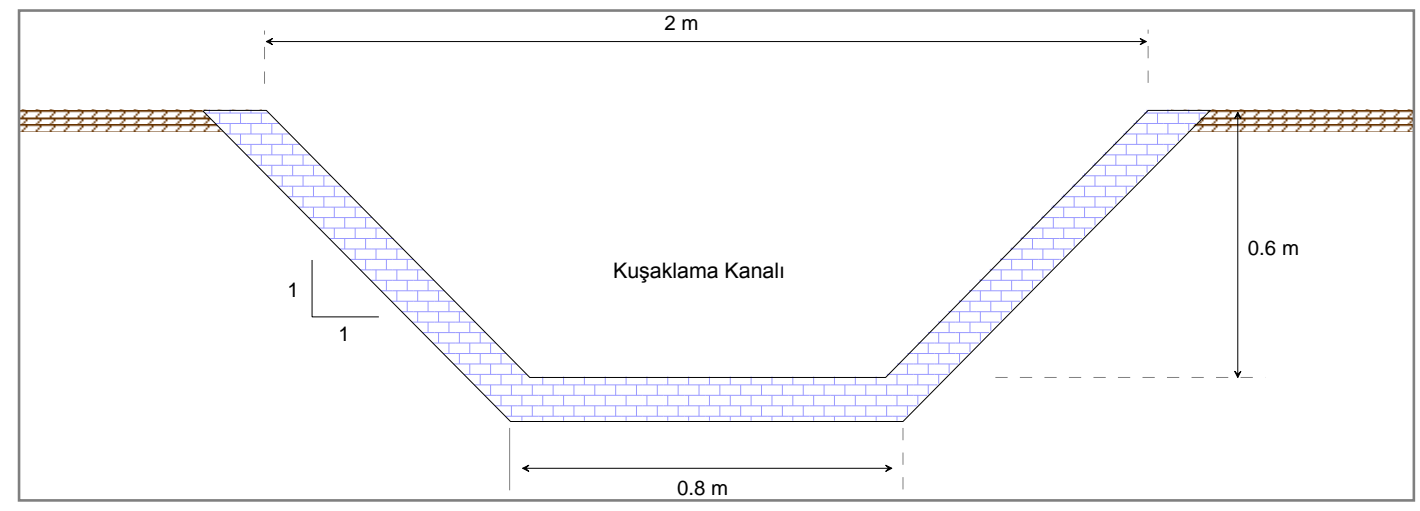

Şekil 9. Çevre suları uzaklaştırma kanalı (kuşaklama) kesiti

3.5. Depolama Alanı Ana Sedde Hacim ve Stabilite Hesabı

Kül depolama alanına 10 yılda yaklaşk $3.500 .000 \mathrm{~m}^{3}$ (4.200.000 ton) kül depolanması planlanmaktadır.
Bu çerçevede $591 \mathrm{~m}$ uzunluğunda $35 \mathrm{~m}$ yükseklik, $5 \mathrm{~m}$ üst genişlik ve $25 \mathrm{~m}$ alt genişlikte $310.275 \mathrm{~m}^{3}$ $(620,550 \mathrm{t})$ hacminde sedde inşa edilecektir.

- $\quad$ Sürtünme Katsayısı $\mu=0,57$

- Ana sedde: Sıkıştırılmış Sert küskülük +Kaya Özgül Ağırlığı = 2,2 t/m²

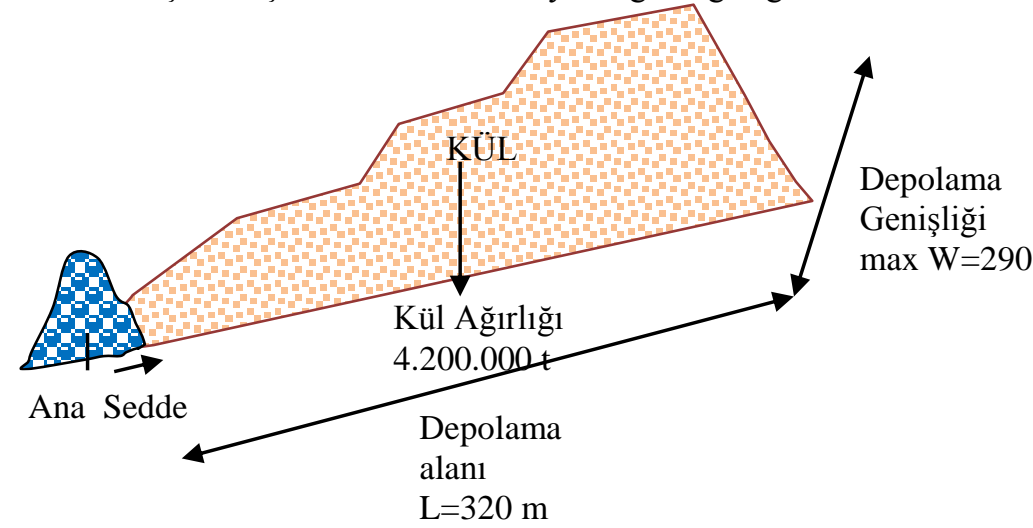

Şekil 10. Sedde hacim ve stabilite hesab1 


\section{Negatif kuvvetler:}

Külün Etkisi:

Depolanacak toplam kül ağırlığı 4,200,000 ton

Bu ağırlığın 1/3 oranı topuk seddeye etki edecektir.

Diğer yükler yanal dağılımla yan seddelere

aktarılacaktır.

Kül yığının tabanı \%3 eğimde $\left(2^{\circ}\right)$ inşa edilecektir.

$\mathrm{Bu}$ durumda topuk seddeye gelen kül yükü:

$\mathrm{G}=4,200,000$ ton* $1 / 3=1,400,000$ ton

$\mathrm{G}_{\mathrm{k}}=1,400,000 \times \operatorname{Sin} 2^{\circ}$

$\mathrm{G}_{\mathrm{k}}=48,859,3$ ton

Daha emniyetli tarafta kalmak için eğim (eğim $1 / 3$

$=18^{\circ}$ ) dikkate alınacaktır. Bu durumda;

$\mathrm{G}_{\mathrm{k}}=1,400,000 \times \operatorname{Sin} 18^{\circ}$

$\mathrm{G}_{\mathrm{k}}=432,623,792$ ton

\section{Pozitif kuvvetler (karșı koyan kuvvetler):}

Sedde uzunluğu $=591 \mathrm{~m}$

Sedde yüksekliği $=35 \mathrm{~m}$

Sedde üstü genişliği $=5 \mathrm{~m}$

Sedde taban genişliğ $i=25 \mathrm{~m}$

Toplam sedde hacmi $=591 \times 35 \times(20+5) / 2=$ $310,275 \mathrm{~m}^{3}$

$\mathrm{G}=310,275 \mathrm{~m}^{3} \times 2,2\left(\mathrm{t} / \mathrm{m}^{3}\right)=682,605 \mathrm{t}$

Seddenin zemin sürtünmesi: Sürtünme katsayıs1,

$\mu=0,57$ kabulüyle

$\mathrm{F}=\mathrm{G} \cdot \mu \cdot \cos \alpha$

$\mathrm{F}=682,605 \times 0,57 \times \operatorname{Cos} 0^{\circ}=389,084,85$ ton

Pasif zemin etkisi: $\mathrm{F}_{\mathrm{P}}=1 / 2 \times \gamma \times \mathrm{Kp} \times \mathrm{h}^{2}$

Sedde $3 \mathrm{~m}$ zemin içinde $\gamma=2,2 \mathrm{t} / \mathrm{m}^{3} \mathrm{Kp}=3,0 \mathrm{~h}=3 \mathrm{~m}$

$\mathrm{F}_{\mathrm{P}}=1 / 2 \times 2,2 \times 3,0 \times 4^{2}$

$\mathrm{F}_{\mathrm{P}}=29,7 \mathrm{t} / \mathrm{m}$

$\mathrm{F}=29,7 \mathrm{t} / \mathrm{m} \times 591 \mathrm{~m}=17,552,7$ ton

Külün zemin sürtünmesi: Sürtünme katsayıs1,

$\mu=0.10$ kabulüyle

$\mathrm{F}=\mathrm{G}_{\mathrm{k}} \cdot \mu \cdot \cos \alpha$

$\mathrm{F}=432,623,792 \times 0,1 \times \operatorname{Cos} 18^{\circ}=41,144,96$ ton

Toplam pozitif (karș koyan) kuvvet;

$$
\sum F=389,084,85 \mathrm{t}+17,552,7 \mathrm{t}+41,144,96
$$$$
\mathrm{t}=447,782,5 \text { ton }
$$

$447,782,5$ ton $>432,623,792$ ton olduğundan sedde yeterlidir. $\mathrm{Bu}$ hesap yapılırken dolgu yapılan külün $1 / 3$ 'ü $1 / 3$ eğimle ana seddeye etki edeceği düşünülmüştür.

\subsection{Tesis Çiti}

Kül depolama sahası, tüm tesis alanı çevresini içine alacak şekilde, depolama sahasına giriş ve çıkışın kontrol edilebilmesi, atık malzemenin uçuşarak taşınmasını önlemek ve yaban hayvanlarının saha içine girişini engellemek için 1392 m uzunlukta tel çit ile çevrelenecektir.

\subsection{Tesis Yolları}

Kül depolama sahasında dört tip yol planlanmıştır. Şekil 6'da gösterilen yollar ve özellikleri aşağıda açıklanmıştır:

Yol.1 Tesis Giriş Yolu; Saha girişinden kontrol yoluna (Yol 2) ve sizintı suyu havuzunu çevreleyen (Yol 3) bağlantıyı sağlayan yoldur. Genişliği 7,0 m uzunluğu 416 m'dir.

Yol.2 Kontrol Yolu; $\mathrm{Bu}$ yol, özellikle kül depolama sahasının işletme ve işletme sonrasında her türden kontrolünün yapılabilmesi için öngörülmüştür. Genişliği 7,0 m uzunluğu 1181 m'dir.

Yol.3 Kontrol Yolu; S1zınt1 suyu havuzunu çevreleyen yoldur ve genişliği $5 \mathrm{~m}$ uzunluğu 192 m'dir.

Atık Kamyon Yolu; yukarıda bahsi geçen yollara ilave olarak sahanın işletilmesi esnasında Atık Kamyon Yolu olarak adlandırılabilecek bir yolun teşkil edilmesi söz konusu olacaktır. Söz konusu yol depolama sahasının kenarından, yani seddeden itibaren, atık döküm alanına erişimi sağlayacak geçici yoldur. Atık döküm alanı zamana bağlı olarak şekil değiştirerek atık yüksekliği artacağından, bu yolun da güzergahı değişecektir. Dolayısıyla, işletme planına ve dolum ilerlemesine bağlı olarak uygulanacaktır.

\subsection{Tozumaya Karşı Alınacak Önlemler}

Hava Kalitesi Değerlendirme ve Yönetimi Yönetmeliği [17]'e göre açıkta depolanan yığma malzeme, hava kalitesi koşullarını sağlamak şartı ile açıkta depolanabilir. Bu amaçla; araziye rüzgar kesici levhalar yerleştirilecek, duvar örülecek veya 
rüzgar kesici ağaçlar dikilecek, savurma yapılmadan doldurma ve boşaltma yapılacak ve tesiste açıkta depolanan yı̆̆ma malzemelerinin hava kalitesi koşullarını sağlayabilmesi için gerekli tedbirler alınacaktır. Tesis içi yollar düzenli olarak temizlenecek, tozumaya karşı her türlü önlem alınacak ve yollar bitümlü kaplama malzemeleri ve/veya beton malzemeler ile kaplanacaktır.

\section{SONUÇ VE ÖNERILLER}

Faaliyeti sona eren taş ocaklarının doğaya tekrar kazandırılması hem çevresel etkileri hem de estetik açıdan önem arz etmektedir. Özellikle İskenderunAdana otoyolu boyunca irili ufaklı çok sayıda taş ocağı yer almaktadır. Ayrıca, yörede sayıları gittikçe artan çok sayıda sanayi ve termik santral yer almaktadır. Bir taraftan termik santrallerin külleri ve çelikhane cürufları gibi katı atıklar görsel ve çevresel tehdit oluştururken, diğer taraftan taş ocaklarının ocak çukurları görsel ve çevresel tehdit oluşturmaktadır. $\mathrm{Bu}$ çalışmada Madencilik Faaliyetleri ile Bozulan Arazilerin Doğaya Yeniden Kazandırılması Yönetmeliği [6] ile Atıkların Düzenli Depolanmasına Dair Yönetmelik [9] çerçevesinde söz konusu çevresel tehditlerin bertarafına çözüm getirilmiştir. Bu kapsamda faaliyeti sona erecek bir taş ocağ1 maksimum atık depolamaya özen gösterilecek şekilde tasarlanmıştır. Tasarım çalışmaları, atık miktarının tamamının depolanmasına ve düzenli depolama kriterlerine uyulmasına yönelik olarak yürütülmüştür. $97,200 \mathrm{~m}^{2}$ alan ve 4,159,776,00 m depolama hacmine sahip Kül Depolama Alanı'nda Termik Santrali'nden kaynaklanacak ve 10 yıl süre ile toplam miktarının yaklaşı $3,500,000 \mathrm{~m}^{3}$ olacağı öngörülen külün depolanması planlanmıştır.

\section{KAYNAKLAR}

1. Goudie, A., 2000. The Human Impact on the Natural Environment, Blackwell, Oxford, UK.

2. Lin, C., Tong, X., Lu, W., Yan, L., Wu, Y., Nie, C., Chu, C. Long, J., 2005. Environmental Impact of Surface Mining on Mined Lands, Affected Stream Sand Agricultural Lands in the Dabaoshan Mine Region, Southern China.
Land Degradation \& Development 16, s.463474.

3. Nieman, T.J. Merkin, Z.R., 1995. Wildlife Management, Surface Mining, and Regiona Lplanning. Growth and Change 26, s. 405-424.

4. Willis, K.G. Garrod, G.D., 1999. Externalities From Extraction of Aggregates: Regulation by tax or Land-Use Controls. Resources Policy 25, s. 77-86.

5. Ziev, Z., 1985. Direct and Indirect Hazards Caused by Quarries. Land 26, s. 35-44.

6. Madencilik Faaliyetleri ile Bozulan Arazilerin Doğaya Yeniden Kazandırılmasına Dair Yönetmelik, 2010. 27471, 23 Ocak 2010.

7. Down G. Stocks J., 1977. Environmental Impact of Mining, Essex: Science Publishers Ltd., sf. 11-17.

8. Ramani R.V., Sweigard, R.J., Clar, M.L., 1990. Reclamation Planning-Surface Mining Mandbook, USA., s. 750-769.

9. Atıkların Düzenli Depolanmasına Dair Yönetmelik, 2010. T.C. Resmi Gazete, 27533, 26 Mart 2010.

10. Microsoft Corporation, 2006. Microsoft Office Excel 2007, Bilgisayar Program1, Redmond, Washington, USA.

11. Golden Software, 2002. Surfer: User's Guide, Colorado, Golden Software, 664 p.

12. Mapinfo Corporation, 2007. Map Info Professional 9.0 User Guide, Newyork, s. 551.

13. Aksay, A., Tekeli, O., Ürgün, B.M. Işık, A., 1988. Amanoslar'in Paleozoyik Birimleri ve Mesozoyik Platform Karbonat İstifleri: MTA Rapor No. 8312, Ankara, (yayımlanmamış).

14. Atan, O.R., 1969. Eğribucak-Karacaören (Hassa)-Ceylanl1-Dazevleri (K1rıkhan) Arasındaki Amanos Dağları'nın Jeolojisi, MTA Yayınları no.139, 85, Ankara.

15. Herece, E., 2008. Doğu Anadolu Fayı Atlas1, 036 Paftası DAF Boyu Jeoloji Haritası, MTA Özel Yayın Serisi-13, Ankara.

16. Manning R., 1891. On Theflow of Water in Open Channel Sand Pipes, Transactions of the Institution of Civil Engineers of Ireland, 20, s. 161-207.

17. Hava Kalitesi Değerlendirme ve Yönetimi Yönetmeliği, 2008. T.C. Resmi Gazete, 26898, 06 Haziran 2008. 
